\title{
Tensile bond strength of glass fiber posts luted with different cements
}

\author{
Resistência à tração de pinos de fibra de vidro \\ cimentados com diferentes materiais
}

\begin{abstract}
Gerson Bonfante(a)
Osvaldo Bazzan Kaizer ${ }^{(b)}$

Luiz Fernando Pegoraro(a)

Accácio Lins do Valle ${ }^{(a)}$
\end{abstract}

(a) PhDs, Professors, Department of Prosthodontics, School of Dentistry of Bauru, University of São Paulo.

(b) PhD, Professor, Department of Restorative Dentistry, School of Dentistry of Santa Maria, Federal University of Santa Maria.

\section{Corresponding author:}

Osvaldo Bazzan Kaizer

Rua Tuiuti, 2121, apto. 902

Santa Maria - RS - Brazil

CEP: 97015-000

E-mail: obekaizer@terra.com.br

Received for publication on Aug 31, 2006 Sent for alterations on Oct 18, 2006 Accepted for publication on Feb 08, 2007

\begin{abstract}
Proper selection of the luting agent is fundamental to avoid failure due to lack of retention in post-retained crowns. The objective of this study was to investigate the tensile bond strength and failure mode of glass fiber posts luted with different cements. Glass fiber posts were luted in 40 mandibular premolars, divided into 4 groups $(n=10)$ : Group 1 - resin-modified glass ionomer RelyX Luting; Group 2 - resin-modified glass ionomer Fuji Plus; Group 3 - resin cement RelyX ARC; Group 4 - resin cement Enforce. Specimens were assessed by tensile strength testing and light microscopy analysis for observation of failure mode. The tensile bond strength values of each group were compared by ANOVA and Tukey test. The significance level was set at $5 \%$. The failure modes were described as percentages. The following tensile strength values were obtained: Group 1 247.6 N; Group $2-256.7$ N; Group 3 - 502.1 N; Group 4 - 477.3 N. There was no statistically significant difference between Groups 1 and 2 or between Groups 3 and 4, yet the resin cements presented significantly higher tensile bond strength values than those presented by the glass ionomer cements. Group 1 displayed $70 \%$ of cohesive failures, whereas Groups 2, 3 and 4 exhibited $70 \%$ to $80 \%$ of adhesive failures at the dentin-cement interface. We concluded that resin cements and glass ionomer cements are able to provide clinically sufficient retention of glass fiber posts, and that glass ionomer cements may be especially indicated when the application of adhesive techniques is difficult.
\end{abstract}

Descriptors: Post and core technique; Tensile strength; Resin cements; Glass ionomer cements.

Resumo: A seleção adequada do agente cimentante é essencial para evitar falhas por perda de retenção em coroas retidas por núcleos. O objetivo deste estudo foi investigar a resistência à tração e o tipo de falha de pinos de fibra de vidro cimentados com diferentes materiais. Cimentaram-se pinos de fibra de vidro em 40 pré-molares inferiores, divididos em 4 grupos $(n=10)$ : Grupo 1 - ionômero de vidro modificado por resina RelyX Luting; Grupo 2 - ionômero de vidro modificado por resina Fuji Plus; Grupo 3 - cimento resinoso RelyX ARC; Grupo 4 - cimento resinoso Enforce. Avaliaram-se os espécimes por teste de resistência à tração e análise por microscopia óptica para observação do tipo de falha. Compararam-se os valores de resistência à tração de cada grupo por análise de variância e teste de Tukey, sendo que o nível de significância estabelecido foi de 5\%. Descreveramse os tipos de falha na forma de porcentagens. Os valores de resistência à tração obtidos foram: Grupo 1 - 247,6 N; Grupo 2 - 256,7 N; Grupo 3 - 502,1 N; Grupo 4 - 477,3 N. Não houve diferença estatisticamente significativa entre os Grupos 1 e 2 ou entre os Grupos 3 e 4, porém os cimentos resinosos apresentaram valores de resistência à tração significativamente maiores do que os apresentados pelos cimentos ionoméricos. O Grupo 1 exibiu $70 \%$ de falhas coesivas, enquanto os Grupos 2, 3 e 4 apresentaram $70 \%$ a $80 \%$ de falhas adesivas na interface dentina-cimento. Concluiu-se que os cimentos resinosos e ionoméricos são capazes de proporcionar retenção clinicamente suficiente de pinos de fibras de vidro, e que os cimentos ionoméricos podem ser indicados principalmente quando houver dificuldades de aplicar técnicas adesivas.

Descritores: Técnica para retentor intra-radicular; Resistência à tração; Cimentos de resina; Cimentos de ionômeros de vidro. 


\section{Introduction}

Post-retained crowns may present mechanical or biological failures, ${ }^{11}$ commonly due to loss of retention. ${ }^{20}$ Thus, root canal posts should have enough tensile bond strength to avoid displacement during function. ${ }^{3,19}$ The main function of posts is to aid in crown retention, ${ }^{8}$ especially when $50 \%$ or more of the remaining coronal structure have been lost. ${ }^{8,13}$

The quality of the cement is fundamental for post retention; however, there is no consensus in the literature as to the superiority of one cement compared to others, since the outcomes of tensile bond strength studies are conflicting. ${ }^{5,15,16}$ Moreover, no luting agents have all ideal properties. ${ }^{5}$

Zinc phosphate is still the luting agent most often employed, ${ }^{16}$ and it is the first choice for posts with adequate mechanical retention when fluoride release is not essential since it presents a long history of reliability and clinical success. ${ }^{5,16}$ It is used as standard in comparative studies. ${ }^{21}$ Its main disadvantages are high clinical solubility and lack of adhesion to the tooth structure. ${ }^{16}$

Resin cements are indicated only when post retention is severely impaired. ${ }^{5}$ However, these cements are highly technique-sensitive, are affected by moisture and require extended chair time. ${ }^{13}$ Moreover, the shorter working time, high viscosity and possibility of accumulation of adhesive ${ }^{13}$ preclude its application in narrow root canals, with risk of incomplete fitting of the post. ${ }^{2}$

Bonding of resin cements is mainly impaired by unfavorable root canal configuration, related to a high $\mathrm{C}$ factor (cavity configuration factor), which may be up to 40 times higher compared to direct intracoronal restorations with similar cement thickness. ${ }^{26}$ The $\mathrm{C}$ factor is the ratio between the bonded and non-bonded surface areas. The latter allows resin flow with consequent decrease in polymerization shrinkage stress. ${ }^{22}$ When the non-bonded area is minimum, as inside the root canals, stress decrease is not enough and polymerization shrinkage may be higher than the bond strength, leading to the formation of gaps at the cement-dentin interface. ${ }^{26}$

Since the bonding of root canal posts with resin cements is highly unpredictable, ${ }^{26}$ conventional glass ionomer cements (GIC) or resin-modified glass iono- mer cements (RMGIC) ${ }^{3}$ may be alternatively indicated for the luting of fiber posts. Both cements present bonding to dentin by micromechanical mechanisms and chemical bonding, ${ }^{6}$ and, despite the polymerization shrinkage they present, their more favorable viscoelastic properties (viscosity and modulus of elasticity), compared to those of resin cements (which are more rigid), and their longer setting time allow a better maintenance of the bonding. ${ }^{3,6}$ Moreover, the hygroscopic expansion occurring after maturation of GIC e RMGIC partially compensates for shrinkage, thus reducing the stress and providing a closer adaptation between cement and dentin at completion of maturation. ${ }^{27}$ The RMGIC intend to keep the advantages of GIC and minimize their most significant disadvantages: They are less sensitive to moisture, present higher dimensional stability and higher bonding to the tooth structure than GIC. They also release fluoride, are easily prepared and are more resistant to compression than zinc phosphate cement. ${ }^{5,21}$

A recent study ${ }^{10}$ with the push-out technique suggested that the resistance to displacement of fiber posts is more related to friction than to true bonding to the root canal. Therefore, GIC and RMGIC may be used for fiber post luting since their hygroscopic expansion $^{6}$ increases the frictional resistance to post displacement. Also, no significant differences in microleakage have been observed between carbon fiber posts luted with resin cement Panavia 21 or glass ionomer cement Fuji-I. ${ }^{21}$

This study investigated the tensile bond strength of glass fiber posts luted with different cements and the failure mode occurring for each cement. The null hypothesis was that there would be no differences in tensile bond strength or failure mode between luting agents.

\section{Materials and Methods}

Forty roots of endodontically treated singlerooted mandibular premolars were selected, with a mean length of $15 \mathrm{~mm}$ and cervical diameter ranging from 5 to $5.5 \mathrm{~mm}$ in the mesiodistal direction and 7 to $7.5 \mathrm{~mm}$ in the buccolingual direction. The root canals in the four groups were prepared up to a depth of $10 \mathrm{~mm}$ using a Largo bur n. 4 (Dentsply 
Maillefer, Ballaigues, Switzerland), as recommended by the manufacturer of the glass fiber posts (Reforpost n. 2, Odonto-Lógika Ltda., Londrina, Paraná, Brazil). The posts had a cylindrical shape $(1.25 \mathrm{~mm}$ in diameter) and a tapered apex $(0.9 \mathrm{~mm}$ in diameter in the final $3 \mathrm{~mm}$ ), in addition to large mechanical undercuts throughout their extension.

The roots were fixed to plastic cylinders with self-curing acrylic resin, keeping $3 \mathrm{~mm}$ of root exposed. Before luting, the root canals were cleaned, rinsed with distilled water for 60 seconds and dried with suction and paper points. The specimens were randomly divided into 4 groups $(\mathrm{n}=10)$, as follows:

- Group 1 - Posts luted with resin-modified glass ionomer cement RelyX Luting (3M ESPE, St. Paul, MN, USA). The cement was prepared following the manufacturer's instructions and mixed for 30 seconds. The mixture was applied on the post and inserted into the root canal with a Lentulo spiral. The posts were fitted under finger pressure and submitted to a 2-kg static load for 10 minutes.

- Group 2 - Posts luted with resin-modified glass ionomer cement Fuji Plus (GC America, Alsip, IL, USA). The root canal dentin was previously etched with Fuji Plus Conditioner for 20 seconds, followed by thorough rinsing with distilled water and drying with paper points. The cement was prepared following the manufacturer's instructions and mixed for 20 seconds. Luting was then performed as described for Group 1.

- Group 3 and Group 4 - Posts luted with dualcure resin cements. Group 3 was luted with resin cement RelyX ARC (3M ESPE, St. Paul, MN, USA) and Group 4 with the cement Enforce (Dentsply Ind. e Com., Rio de Janeiro, RJ, Brazil). Acid etching of the root canal walls was performed with $37 \%$ phosphoric acid for 15 seconds, followed by thorough rinsing and drying with endodontic canula and paper points. The adhesive system Scotchbond Multi-Purpose Plus (3M ESPE, St. Paul, MN, USA) was applied on the root canal walls, carefully following the manufacturer's instructions to achieve dual cure. The post was cleaned with ethyl alcohol and a coat of silane (Scotchbond Ceramic Primer, 3M
ESPE, St. Paul, MN, USA) was applied for one minute, gently air-dried, and the catalyst of the adhesive system Scotchbond Multi-Purpose Plus was applied.

After cement preparation following the manufacturer's instructions for 10 to 20 seconds, luting was performed as described for Group 1, followed by light curing (XL 2500, 3M ESPE, St. Paul, MN, USA) for 40 seconds.

\section{Tensile bond strength testing}

The coronal portion of the post was fabricated with light cured composite resin Filtek Z250 (3M ESPE, St. Paul, MN, USA), applied in $2-\mathrm{mm}$ increments. To avoid adhesion of resin to the root, two sheets of tin foil (Alumileste Ind., Cajamar, SP, Brazil) were placed on the dentin for isolation. A $\mathrm{U}$-shaped loop cast in $\mathrm{Ni}-\mathrm{Cr}$ alloy was inserted to connect the specimen to the testing machine. After storage of the specimens in distilled water for 24 hours at $37^{\circ} \mathrm{C}$, they were submitted to tensile bond strength testing in a universal testing machine (Model K-2000MP, Dinamômetros Kratos Ltda., Taboão da Serra, SP, Brazil). A metallic pin was placed through a perforation at the lower third of the acrylic resin cylinder for adaptation to the lower articulation of the testing machine. The crosshead speed applied to the specimen (through the hook connected to the upper portion of the testing machine and the loop at the coronal portion of the post) was $0.5 \mathrm{~mm} / \mathrm{min}$.

The failure mode was established by analysis under a light microscope Mitutoyo series 164 (Mitutoyo Corporation, Tokyo, Tokyo, Japan) at a $30 \mathrm{X}$ magnification and classified as follows: ${ }^{17}$

1. adhesive failure at the cement-post interface;

2. adhesive failure at the dentin-cement interface;

3. cohesive failure;

4. combined failure.

The tensile bond strength values of each group were compared by one-way ANOVA and Tukey's test $(\mathrm{p}=0.05)$.

\section{Results}

Table 1 presents the mean tensile bond strength values and standard deviations. The 1-way ANOVA 
Table 1 - Means and standard deviations of tensile bond strength $(\mathrm{N})$ for the cements.

\begin{tabular}{l|c|c}
\hline \multicolumn{1}{c|}{ Groups } & Mean (N) & SD \\
\hline RelyX Luting & 247.6 & 4.7 \\
\hline Fuji Plus & 256.7 & 4.6 \\
\hline RelyX ARC & 502.1 & 9.0 \\
\hline Enforce & 477.3 & 7.7 \\
\hline
\end{tabular}

Table 2 - Failure modes (\%) observed for each group.

\begin{tabular}{l|c|c|c|c}
\hline \multicolumn{1}{c|}{ Failure mode } & $\begin{array}{c}\text { RelyX } \\
\text { Luting }\end{array}$ & Fuji Plus & $\begin{array}{c}\text { RelyX } \\
\text { ARC }\end{array}$ & Enforce \\
\hline $\begin{array}{l}\text { Adhesive at the } \\
\text { dentin-cement interface }\end{array}$ & $1(10 \%)$ & $7(70 \%)$ & $8(80 \%)$ & $7(70 \%)$ \\
\hline $\begin{array}{l}\text { Adhesive at the } \\
\text { post-cement interface }\end{array}$ & - & - & - & - \\
\hline Combined & $2(20 \%)$ & $2(20 \%)$ & $2(20 \%)$ & $3(30 \%)$ \\
\hline Cohesive & $7(70 \%)$ & $1(10 \%)$ & - & - \\
\hline
\end{tabular}

revealed statistically significant differences between groups $(\mathrm{p}<0.05)$. The Tukey test for multiple comparisons revealed that RelyX ARC and Enforce presented significantly higher tensile bond strength values than those presented by the other cements $(\mathrm{p}<0.05)$, without statistically significant differences between RMGIC or between resin cements.

\section{Discussion}

Fiber-reinforced resin posts are the most recent option for the reconstruction of endodontically treated teeth. Even though clinical and laboratory studies on fiber posts are limited, the low number of failures and nearly total absence of root fractures should be highlighted. ${ }^{9,12,14}$ Theoretically, these posts would be able to reinforce weakened roots, without increasing the risk of fracture.

In this study, even though the bond strength values obtained for the RMGIC (Groups 1 and 2) were significantly lower compared to those obtained for Groups 3 and 4 (resin cements), all cements showed proper retention considering that posts should have a minimum tensile bond strength of $200 \mathrm{~N}$ to allow clinical success. ${ }^{17}$ The post configuration (parallel with the tapered apex and undercuts throughout its extension) probably contributed to the retention val- ues of $247.6 \mathrm{~N}$ and $256.7 \mathrm{~N}$ respectively for Groups 1 and 2. Moreover, the retention of posts luted with RMGIC may be related to the frictional retention provided by hygroscopic expansion occurring after cement maturation, ${ }^{27}$ which also aids the self-sealing at the dentin-cement interface.

The highest bond strength values were observed for the resin cements RelyX ARC (502.1 N) and Enforce $(477.3 \mathrm{~N})$. Considering that polymerization of chemically-cured or dual-cured resin cements is impaired by the association with simple (2-step) conventional adhesives or single-step self-etching adhesives, due to the high acidity of these systems, a 3-step dual-cured conventional adhesive was used for both resin cements in the present study. This enhanced the polymerization of the adhesive considering that the access for light curing at the most apical regions is limited. Scotchbond Multi-Purpose Plus has been successfully used since 1992 and has a record of less than $2 \%$ of loss of direct restorations. ${ }^{25}$ Also, the tensile bond strength of self-curing or dual-cured resin cements obtained with this system is higher than the polymerization shrinkage stress produced by the polymerization of thin layers of resin cements in closed spaces, which is nearly $20 \mathrm{MPa}$.

When resin cements were employed, 70 to $80 \%$ of failures occurred at the dentin-cement interface (Table 2), which is in agreement with previous findings ${ }^{1}$ that adhesive failures occurred between the adhesive system and dentin. Bonding to the root canal dentin may be reduced by several unfavorable conditions, such as the materials employed during root canal preparation, eugenol-based endodontic sealers, difficulty to achieve an ideal degree of moisture, insufficient impregnation by the adhesive, and a high $\mathrm{C}$ factor, which is related to root canal configuration. When resin cements were employed, no specimen presented complete failure at the post-resin cement interface, suggesting that the application of silane combined with the mechanical undercuts of the posts was effective to aid the cement against displacement and also suggesting a good bonding between the resin matrix of the fiber posts and the resin cements. ${ }^{18}$ Finally, the lack of observation of cohesive failures in the resin cements is related to their high resistance. ${ }^{23}$ 
Both RMGICs presented different failure modes, despite their similar bond strengths: RelyX presented $70 \%$ of cohesive failures, whereas Fuji Plus exhibited $70 \%$ of adhesive failures between dentin and cement (similarly to the resin cements). Some glass ionomer cements have increased bond strength due to the formation of a hybrid layer in dentin, and HEMA is able to penetrate into the dentinal tubules up to a depth of $1.5 \mathrm{~mm} .{ }^{4,7}$ The failure mode observed for Fuji Plus suggests the formation of a hybrid layer, and dentin pretreatment with a weak acid may have helped in the removal of the smear layer and increased dentin wettability, thereby enhancing adhesion. The low number of cohesive failures observed for Fuji Plus suggests that its resin components (HEMA, TEGDMA) provide it with good mechanical resistance. The failure mode observed for RelyX Luting indicates that retention of this cement probably is more dependent on mechanical retention than on bonding

\section{References}

1. Alster D, Feilzer AJ, de Gee AJ, Davidson CL. Polymerization contraction stress in thin resin composite layers as a function of layer thickness. Dent Mater. 1997;13(3):146-50.

2. Bachicha WS, Difiore PM, Miller DA, Lautenschlager EP, Pashley DH. Microleakage of endodontically treated teeth restored with posts. J Endod. 1998;24(11):703-8.

3. Bouillaguet S, Troesch S, Wataha JC, Krejci I, Meyer JM, Pashley DH. Microtensile bond strength between adhesive cements and root canal dentin. Dent Mater. 2003;19(3):199-205.

4. Carvalho RM, Yoshiyama M, Horner JA, Pashley DH. Bonding mechanism of Variglass to dentin. Am J Dent. 1995;8(5):253-8.

5. Creugers NH, Kayser AF, van't Hof MA. A meta-analysis of durability data on conventional fixed bridges. Community Dent Oral Epidemiol. 1994;22(6):448-52.

6. Dauvillier BS, Feilzer A, de Gee AJ, Davidson CL. Viscoelastic parameters of dental restorative materials during setting. J Dent Res. 2000;79(3):818-23.

7. Ferrari M, Davidson CL. Interdiffusion of traditional glass ionomer cement into conditioned dentin. Am J Dent. 1997;10(6):295-7.

8. Ferrari M, Vichi A, Grandini S, Goracci C. Efficacy of a self-curing adhesive-resin cement system on luting glass-fiber posts into root canals: a SEM investigation. Int J Prosthodont. 2001;149(9):543-9.

9. Fredriksson M, Astback J, Pamenius M, Arvidson K. A retrospective study of 236 patients with teeth restored by to dentin, and the high number of cohesive failures may be associated with its low intrinsic resistance and presence of bubbles within the cement.

All cements investigated in this study provided clinically sufficient retention of glass fiber posts. ${ }^{17,24}$ The results suggest that RMGIC may be indicated for fiber post luting, especially when application of adhesive techniques is difficult.

\section{Conclusions}

Within the limitations of the present study, the following could be concluded:

1. Resin-modified glass ionomer cements may be indicated for luting of glass fiber posts.

2. Posts luted with RelyX Luting presented predominance of cohesive failures, whereas posts luted with Fuji Plus and resin cements exhibited predominance of adhesive failures at the dentin-cement interface.

carbon fiber-reinforced epoxy resin posts. J Prosthet Dent. 1998;80(2):151-7.

10. Goracci C, Fabianelli A, Sadek FT, Papacchini F, Tay FR, Ferrari M. The contribution of friction to the dislocation resistance of bonded fiber posts. J Endod. 2005;31(8):608-12.

11. Hatzikyriakos AH, Reisis GI, Tsingos N. A 3-year postoperative clinical evaluation of posts and cores beneath existing crowns. J Prosthet Dent. 1992;67(4):454-8.

12. Heydecke G, Peters MC. The restoration of endodontically treated, single-rooted teeth with cast or direct posts and cores: a systematic review. J Prosthet Dent. 2002;87(4):380-6.

13. Kimmel SS. Restoration and reinforcement of endodontically treated teeth with a polyethylene ribbon and prefabricated fiberglass post. Gen Dent. 2000;48(6):700-6.

14. Love RM, Purton DG. Retention of posts with resin, glass ionomer and hybrid cements. J Dent. 1998;26(7):599-602.

15. Mendoza DB, Eakle S. Retention of posts cemented with various dentinal bonding cements. J Prosthet Dent. 1994;72(6):5914.

16. Mitchell CA. Selection of materials for post cementation. Dent Update. 2000;27(7):350-4.

17. Monticelli F, Grandini S, Goracci C, Ferrari M. Clinical behavior of translucent-fiber posts: a 2-year prospective study. Int J Prosthodont. 2003;16(6):593-6.

18. Phrukkanon S, Burrow MF, Tays MJ. Effects of cross-sectional surface area on bond strengths between resin and dentin. Dent Mater. 1998;14(2):120-8. 
19. Purton DG, Love RM. Rigidity and retention of carbon fibre versus stainless steel root canal posts. Int Endod J. 1996;29(4):262-5.

20. Sorensen JA, Martinoff JT. Intracoronal reinforcement and coronal coverage: a study of endodontically treated teeth. J Prosthet Dent. 1984;51(6):780-4.

21. Stockton LW. Factors affecting retention of post systems: a literature review. J Prosthet Dent. 1999;81(4):380-5.

22. Tay FR, Loushine RJ, Lambrechts P, Weller RN, Pashley DH. Geometric factors affecting dentin bonding in root canals: a theoretical modeling approach. J Endod. 2005;31(2):584-9.

23. Tay FR, Pashley DG, Yiu CKY, Sanares AME, Wei SHY. Factors contributing to the incompatibility between simpli- fied-step adhesives and chemical-cured or dual-cured composites. Part I. Single-step, self-etch adhesive. J Adhes Dent. 2003;5(1):27-40.

24. Turner CH. The retention of dental posts. J Dent. 1982;10(3):154-65.

25. van Meerbeek B, Perdigao J, Lambrechts P, Vanherle G. The clinical performance of adhesives. J Dent. 1998;26(1):1-20.

26. Watanabe F, Powers JM, Lorey RE. Invitro bonding of prosthodontic adhesives to dental alloys. J Dent Res. 1998;67(2):47983.

27. Yiu CKY, Tay FR, King NM, Pashley DH, Sidhu SK, Neo JCL. Interaction of glass-ionomer cements with moist dentin. J Dent Res. 2004;83(4):283-9. 